Jurnal Wacana Kesehatan

Volume 4, Nomor 2, Desember 2019

e-ISSN 2544-6251

\title{
HUBUNGAN CITRA TUBUH DENGAN STRES PADA PENDERITA DIABETES MELLITUS DI WILAYAH KERJA PUSKESMAS PRINGSEWU
}

\section{RELATIONSHIP BODY IMAGE WITH STRESS ON DIABETES MELLITUS IN PUBLIC WORKING AREA PRINGSEWU}

\author{
${ }^{1}$ Idayati, ${ }^{2}$ Siti Indarti \\ ${ }^{1,2}$ Fakultas Kesehatan Universitas Muhammadiyah Pringsewu Lampung \\ e-mail: idayati.bangsawan@yahoo.com
}

\begin{abstract}
ABSTRAK
Diabetes mellitus merupakan sekelompok kelainan heterogen yang ditandai oleh kenaikan kadar glukosa dalam darah atau hiperglikemia. Penderita Diabetes Mellitus dapat mengalami komplikasi dan dapat menyebabkan penurunan fungsi tubuh dan perubahan fisik. Penderita Diabetes Mellitus yang mengalami perubahan fisik kurang baik pada tubuhnya, mereka cenderung memiliki konsep diri khususnya citra diri yang negatif. Penelitian ini bertujuan untuk mengetahui hubungan citra tubuh dengan stress pada penderita Diabetes Mellitus di wilayah kerja Puskesmas Pringsewu Tahun 2019.Penelitian ini merupakan penelitian analitik korelasi dengan desain CrossSectional dimana populasi 53 orang dan sampel 35 orang. Tekhnik pengambilan sampel menggunakan Purposive Sampling, analisis statistic yang digunakan uji Chi-Square. Hasil penelitian ini menunjukkan $p$-value $0,000<0,05$ ( $p$-value $<0,05)$, hal ini menunjukan bahwa terdapat hubungan citra tubuh dengan stress pada penderita Diabetes Mellitus. Hasil penelitian ini diharapkan dapat menjadi masukan bagi masyarakat khususnya penderita Diabetes Mellitus untuk selalu berfikir positif dalam pencegahan terjadinya stress.
\end{abstract}

Kata kunci: citra tubuh, stress, diabetes mellitus

\begin{abstract}
Diabetes mellitus is a group of heterogeneous disorders characterized by elevated levels of glucose in the blood or hyperglycemia. Diabetics can experience complications and can lead to decreased body function and physical changes. Patients with DM who undergo poor physical changes in their bodies, they tend to have a self-concept, especially a negative self-image. This study aims to determine the relationship of body image with stress in people with diabetes mellitus in the work area of Pringsewu Health Center Year 2019. This research is an analytical research with cross-sectional design where population 53 people and sample 35 people. Technique of sampling using Purposive Sampling, statistic analysis used chi-square test. The results of this study show that $p$-value 0,000 $<0,05$ ( $p$-value $<0,05$ ), this shows that there is a relationship of body image with stress in people with diabetes mellitus. The results of this study is expected to be input for the community, especially people with Diabetes mellitus to always think positive in an effort to prevent the occurrence of stress.
\end{abstract}

Keywords: body image, stress, diabetes mellitus 


\section{PENDAHULUAN}

Penyakit Diabetes Mellitus (DM) merupakan ancaman serius bagi pembangunan kesehatan dan pertumbuhan ekonomi nasional, karena itu pengendaliannya perlu dilakukan dengan sungguh-sungguh, secara komprehensif dan terintegrasi dengan memberikan perhatian melalui pengendalian penyakit tidak menular yaitu healthy diet and healthy activity yang dimulai sejak janin sampai dewasa tua ${ }^{1}$.

Penderita DM dalam jangka panjang dapat menyebabkan komplikasi mikrovaskular, makrovaskular, dan neuropati seperti penyakit arteri koroner (infark miokard), dan penyakit vaskular perifer, ini memberikan gambaran kelainan pada tungkai bawah yang berupa ulkus maupun gangren yang selanjutnya disebut ulkus diabetik $^{2}$. Penderita DM yang mengalami perubahan kurang baik pada tubuhnya, mereka cenderung memiliki konsep diri khususnya citra diri yang negatif. Biasanya seseorang dengan citra tubuh negatif mereka akan menyembunyikan atau tidak melihat hingga tidak menyentuh bagian tubuh yang strukturnya telah berubah akibat penyakit atau trauma ${ }^{2}$.

Citra tubuh atau body image adalah sikap dari diri sendiri yang disadari ataupun yang tidak disadari terhadap tubuhnya ${ }^{3}$. Citra tubuh merupakan kumpulan dari sikap individu yang disadari dan tidak disadari terhadap tubuhnya, termasuk persepsi masa lalu dan sekarang, serta perasaan tentang struktur, bentuk, dan fungsi tubuh $^{4}$. Pada penderita DM selain mengalami citra diri juga akan mengalami stres dalam dirinya. Stres dan DM memiliki hubungan yang sangat erat terutama pada penduduk perkotaan. Tekanan kehidupan dan gaya hidup tidak sehat sangat berpengaruh dan berbagai penyakit yang sedang diderita menyebabkan penurunan kondisi seseorang hingga memicu terjadinya stress ${ }^{5}$.

Berdasarkan data World Health Organization (WHO) pada tahun 2014 prevalensi DM pada semua umur diperkirakan mencapai $2,8 \%$ dari keseluruhan penduduk dunia, dan diperkirakan akan meningkat menjadi 4,4\% pada tahun 2030 . Dan saat ini Indonesia menduduki rangking keempat penderita DM setelah Amerika Serikat, China dan India diantara negara-negara yang memiliki penyandang diabetes terbanyak, dengan populasi penduduk terbesar di dunia ${ }^{1}$.

Di Indonesia menurut hasil Riskesdas 2013 mencapai $5,7 \%$ penderita DM sedangkan pada Riskesdas 2013 mencapai 6,9\% penderita DM. Prevalensi DM akan terus meningkat bersamaan dengan perubahan gaya hidup dan pola konsumsi makanan. Sedangkan di Indonesia prevalensi yang terdiagnosa dokter tertinggi di Yogyakarta (2,6\%), DKI Jakarta (2,5\%), Sulawesi Utara $(2,4 \%)$ dan Kalimantan Timur $(2,3 \%)$ (Riskesdas, 2013). Sementara di provinsi Lampung prevalensi diabetes militus mencapai $0,7 \%{ }^{6}$.

Berdasarkan hasil prasurvey yang telah dilakukan di Puskesmas Pringsewu pada tanggal 19 Maret 2019 pada satu bulan terakhir terdapat 53 populasi penderita DM, dan saat dilakukan wawancara kepada 5 orang penderita, 4 orang mengeluhkan kesulitan tidur, 5 orang 
mudah lelah, 2 orang mengalami penurunan berat badan dan tidak menerima perubahan tubuh yang telah terjadi dan merasa malu dengan bentuk tubuhnya. Dan peneliti tertarik untuk melakukan penelitian tentang "Hubungan Citra Tubuh Dengan Stres Pada Penderita Diabetes Militus di Puskesmas Pringsewu Kecamatan Pringsewu.

\section{METODE}

Penelitian ini menggunakan jenis penelitian analitik korelasi dengan variabel independen citra tubuh, dengan variabel dependen stres. Dalam desain ini menggunkan pendekatan cross sectional yaitu sesuatu penelitian untuk mempelajari dinamika korelasi antara faktorfaktor, resiko dengan efek dengan cara pendeketan, observasi atau pengumpulan data sekaligus pada suatu saat (point time approach).

${ }^{7}$. Penelitian ini menggunakan tehnik Purposive Sampling, sampel dalam penelitian ini adalah 35 responden. Lembar instrumen yang akan digunakan berupa kuesioner. Uji Statistik yaitu uji chi square.

\section{HASIL}

\section{Analisa Univariat}

Tabel 1

Distribusi frekuensi responden berdasarkan usia di Wilayah kerja Puskesmas Pringsewu

\begin{tabular}{lcc}
\hline \multicolumn{1}{c}{ Usia } & Jumlah & Presentase (\%) \\
\hline $\begin{array}{l}\text { Dewasa Awal } \\
\text { (25-39 tahun) }\end{array}$ & 6 & 17,1 \\
Dewasa Akhir (40-60) & 29 & 82,9 \\
\hline \multicolumn{1}{c}{ Total } & 35 & 100 \\
\hline
\end{tabular}

Berdasarkan tabel 1 terlihat bahwa sebagian besar responden di wilayah kerja Puskesmas Pringsewu berusia dewasa akhir (40-60 tahun) dengan presentase mencapai $82,9 \%$ atau 29 responden.

Tabel 2

Distribusi frekuensi responden berdasarkan jenis kelamin di Wilayah kerja Puskesmas Pringsewu

\begin{tabular}{ccc}
\hline Jenis Kelamin & Jumlah & $\begin{array}{c}\text { Presentase } \\
(\%)\end{array}$ \\
\hline Laki-laki & 11 & 31,4 \\
Perempuan & 24 & 68,6 \\
\hline Jumlah & 35 & 100 \\
\hline
\end{tabular}

Berdasarkan tabel 2 terlihat bahwa sebagian besar responden di wilayah kerja Puskesmas Pringsewu berjenis kelamin perempuan yaitu sebanyak 24 responden $(68,6 \%)$.

Tabel 3

Distribusi frekuensi responden berdasarkan pendidikan di wilayah kerja Puskesmas Pringsewu

\begin{tabular}{ccc}
\hline Pendidikan & Jumlah & $\begin{array}{c}\text { Presentase } \\
(\%)\end{array}$ \\
\hline SD & 14 & 40,0 \\
SMP & 8 & 22,9 \\
SMA & 9 & 25,7 \\
Perguruan Tinggi & 4 & 11,4 \\
\hline Jumlah & 35 & 100 \\
\hline
\end{tabular}

Berdasarkan tabel 3 terlihat bahwa sebagian besar responden yang ada di wilayah kerja Puskesmas Pringsewu berpendidikan dasar SD yaitu sebanyak 14 responden (40\%). 


\begin{tabular}{|c|c|c|}
\hline \multicolumn{3}{|c|}{$\begin{array}{c}\text { Tabel } 4 \\
\text { Distribusi frekuensi responden berdasarkan } \\
\text { pekerjaan di wilayah kerja Puskesmas } \\
\text { Pringsewu }\end{array}$} \\
\hline Pekerjaan & Jumlah & Presentase $(\%)$ \\
\hline IRT & 14 & 40,0 \\
\hline Pegawai Swasta & 7 & 20,0 \\
\hline PNS & 3 & 8,6 \\
\hline Lain-lain & 11 & 31,4 \\
\hline Jumlah & 35 & 100 \\
\hline
\end{tabular}

Berdasarkan tabel 4. terlihat bahwa sebagian besar responden yang ada di wilayah kerja Puskesmas Pringsewu memiliki pekerjaan sebagai ibu rumah tangga yaitu sebanyak 14 responden $(40 \%)$.

\section{Tabel 5}

Distribusi frekuensi responden berdasarkan citra tubuh di wilayah kerja Puskesmas Pringsewu

\begin{tabular}{ccc}
\hline Citra Tubuh & Jumlah & Presentase (\%) \\
\hline Positif & 12 & 34,3 \\
Negatif & 23 & 65,7 \\
\hline Jumlah & 35 & 100 \\
\hline
\end{tabular}

Berdasarkan tabel 5 terlihat bahwa sebagian besar responden yang ada di wilayah kerja Puskesmas Pringsewu memiliki citra tubuh negatif yaitu sebanyak 23 responden $(65,7 \%)$.

Tabel 6

Distribusi frekuensi responden berdasarkan kejadian stres di wilayah kerja Puskesmas Pringsewu

\begin{tabular}{ccc}
\hline Stres & Jumlah & Persentase \\
\hline Normal & 15 & 42,9 \\
Stres & 20 & 57,1 \\
\hline Jumlah & 35 & 100 \\
\hline
\end{tabular}

Berdasarkan tabel 6 terlihat bahwa sebagian besar responden yang ada di wilayah kerja Puskesmas Pringsewu mengalami stres yaitu sebanyak 20 responden $(57,1 \%)$.

\section{Analisa Bivariat}

Tabel 7

Hubungan Citra tubuh dengan stres pada penderita diabetes mellitus di wilayah kerja Puskesmas Pringsewu

\begin{tabular}{|c|c|c|c|c|c|c|c|c|}
\hline \multirow{3}{*}{$\begin{array}{c}\text { Citra } \\
\text { Tubuh }\end{array}$} & \multicolumn{4}{|c|}{ Stres } & & & \multirow{3}{*}{$\begin{array}{c}P \\
V a \\
\text { lue }\end{array}$} & \multirow{3}{*}{ OR } \\
\hline & \multicolumn{2}{|c|}{ Normal } & \multicolumn{2}{|c|}{ Stres } & \multicolumn{2}{|c|}{ Total } & & \\
\hline & $\mathbf{N}$ & $\%$ & $\mathbf{N}$ & $\%$ & $\mathbf{N}$ & $\%$ & & \\
\hline Positif & 11 & 91,7 & 1 & 8,3 & 12 & 100 & $\begin{array}{l}0,0 \\
00\end{array}$ & $\begin{array}{c}52,2 \\
50\end{array}$ \\
\hline Negatif & 4 & 17,4 & 19 & 82,6 & 23 & 100 & & \\
\hline Total & 15 & 42,9 & 20 & 57,1 & 35 & 100 & & \\
\hline
\end{tabular}

Berdasarkan tabel 7 diketahui responden dengan citra tubuh positif yang mengalami normal atau tidak mengalami stres sebanyak 11 responden $(91,7 \%)$ dan responden yang memiliki citra tubuh negatif yang mengalami stres yaitu sebanyak 19 responden $(82,6 \%)$.

Berdasarkan hasil uji statistik diketahui bahwa $p$-value yaitu $0,000<0,05$ ( $p$-value $<0,05)$. Hal ini menunjukan bahwa terdapat hubungan citra tubuh dengan stres pada penderita diabetes mellitus di wilayah kerja Puskesmas Pringsewu Tahun 2019. Hasil pengolahan data juga didapatkan nilai OR sebesar 52,250 yang berarti responden dengan yang memiliki citra tubuh negatif beresiko mengalami stres 52,250 kali lebih besar dibandingkan dengan responden yang memiliki citra tubuh positif. 


\section{Pembahasan}

\section{a. Citra Tubuh}

Dari hasil penelitian yang dilakukan kepada 35 responden di Puskesmas Pringsewu dadapatkan hasil analisa menunjukan sebagian besar responden yang ada di wilayah kerja Puskesmas Pringsewu memiliki citra tubuh negatif yaitu sebanyak 23 responden $(65,7 \%)^{8}$.

Menjelaskan terdapat beberapa faktor yang dapat mempengaruhi citra tubuh seseorang salah satunya adalah kondisi fisik pasien. Pasien Diabetes mellitus yang menahun atau memiliki komplikasi cenderung memiliki citra tubuh yang negatif terhadap dirinya. Citra tubuh seseorang dapat berubah seiring perubahan yang terjadi pada anatomi tubuh atau fungsi tubuh sehingga akan mempengaruhi gambaran diri seseorang. Citra tubuh yang negatif tersebut disebabkan oleh manifestasi klinis yang mengakibatkan penderitanya kehilangan berat badan, penglihatan kabur yang tidak diinginkan serta ulkus diabetikum yang sulit untuk disembuhkan yang mengganggu karakteristik dan sifat seseorang dan penampilannya ${ }^{8}$.

Hasil penelitian ini sesuai dengan pendapat $^{8}$ bahwa sikap seseorang terhadap tubuhnya baik secara sadar atau tidak sadar. Persepsi dan perasaan tentang ukuran dan bentuk, fungsi, penampilan serta potensi tubuh saat ini dan masa lalu. Jika individu menerima dan menyukai dirinya, merasa aman dan bebas dari rasa cemas disebut self esteem meningkat.

\section{b. Stres}

Dari hasil penelitian yang dilakukan kepada 35 responden di Puskesmas Pringsewu dadapatkan hasil penelitian ini menunjukan bahwa sebagian besar responden yang ada di wilayah kerja Puskesmas Pringsewu mengalami stres yaitu sebanyak 20 responden $(57,1 \%)$.

Menurut Kusumawati stres dapat dipengaruhi oleh penyakit yang bersifat kronis salah satunya adalah Diabetes Mellitus. Pasien yang memiliki riwayat menderita Diabetes Mellitus yang lama cenderung akan memiliki komplikasi yang semakin berat. Komplikasi kronis biasanya menampakkan diri setelah 10-15 tahun sejak diagnosis diabetes atau bisa juga sebelum diagnosis Diabetes Mellitus ditegakkan sudah terdapat komplikasi. Salah satu komplikasi yang sering muncul pada penederita Diabetes Meliitus adalah ulkus diabetikum. Komplikasi yang terjadi merupakan penyebab utama terjadinya stres pada pasien Diabetes Meliitus. Pembatasan dan pemilihan diit juga merupakan salah satu penyabab munculnya stres pada pasien Diabetes Mellitus9.

Menurut Nasir, A. dkk mengatakan bahwa selain mengganggu sistem tubuh, stres juga dapat menyebabkan gangguan perasaan seperti gelisah, takut, sedih, merasa rendah diri, iri hati, pemarah, bombing dan ragu serta cemas dapat juga mengganggu pemikiran, seperti tidak dapat berpikir secara jernih, sering lupa, daya pikir rendah, dan tidak dapat berkonsentrasi. Berpengaruh terhadap perilaku, seperti 
menyakiti diri sendiri dan menyakiti orang lain. Memacu berbagai penyakit: jenis penyakit yang sering disebut psikosomatik, misal maag, sesak nafas, diabetes dan hipertensi ${ }^{10}$.

\section{c. Hubungan Citra tubuh dengan stres}

Analisis hubungan citra tubuh dengan stres pada penderita diabetes mellitus di wilayah kerja Puskesmas Pringsewu Tahun 2018. Berdasarkan hasil uji statistik Chi-square diketahui bahwa $p$ value $0,000<0,05$ ( $p$-value $<0,05)$, sehingga Ho ditolak. Hal ini menunjukan bahwa terdapat Hubungan Citra tubuh dengan stres pada penderita diabetes mellitus di wilayah kerja Puskesmas Pringsewu Tahun 2019. Hasil pengolahan data juga didapatkan nilai OR sebesar 52,250 yang berarti responden dengan yang memiliki citra tubuh negatif beresiko mengalami stres 52,250 kali lebih besar dibandingkan dengan responden yang memiliki citra tubuh positif.

DM terbagi menjadi 2 tipe yaitu tipe 1 dan tipe 2. Individu yang menderita DM tipe 1 memerlukan suplai insulin dari luar (eksogen insulin), seperti injeksi untuk mempertahankan hidup, sedangkan Individu dengan DM tipe 2 resisten terhadap insulin, suatu kondisi dimana tubuh atau jaringan tubuh tidak berespon terhadap aksi dari insulin. Sehingga individu tersebut harus selalu menjaga pola makan, selalu melakukan perawatan kaki, mencegah terjadinya hipoglikemi atau hiperglikemi dan hal tersebut akan berlangsung secara terus menerus sepanjang hidupnya ${ }^{11}$.
Hiperglikemia terjadi kerusakan akibat sel $\beta$ pankreas yang menimbulkan peningkatan pengeluaran glukosa oleh hati. Ketika kadar glukosa darah meningkat sampai jumlah glukosa yang difiltrasi melebihi kapasitas, sehingga selsel tubulus melakukan reabsorbsi maka glukosa akan timbul di urin. Glukosa di urin menimbulkan efek osmotik yang menarik air bersaamanya menimbulkan dieresis osmotik yang ditandai oleh poliuria (sering berkemih) cairan yang berlebihan mengakibatkan dehidrasi. Gejala lain adalah rasa haus yang berlebihan merupakan komponen tubuh untuk mengatasi dehidrasi akibat poliuria karena terjadi difisiensi glukosa intra sel, maka kompensasi tubuh merangsang saraf sehingga nafsu makan akan meningkat dan timbul pemasukan makanan berlebihan (polipagia). Akan tetapi terjadi peningkatan pemasukan makanan, berat badan menurun secara progresif akibat defisiensi insulin pada metabolisme lemak dan protein ${ }^{5}$. Hasil penelitian ini sejalan dengan penelitian yang dilakukan menunjukkan hubungan stres dengan citra tubuh pada penderita diabetes mellitus tipe II di Rumah Sakit Pancaran Kasih GMIM Manado. Hasil penelitian ini menujukan bahwa terdapat hubungan antara stres dengan citra tubuh pada pasien Diabetes Mellitus ${ }^{10}$.

Menurut pendapat peneliti citra tubuh yang dimiliki pasien merupakan salah satu faktor utama yang menyebabkan terjadinya stres pada pasien Diabetes Mellitus. Responden yang memiliki citra tubuh negatif beresiko memiliki 
stres lebih besar hal ini disebabkan penurunan fungsi tubuh seperti penglihatan mulai rabun, ulkus diabetikum baik kaki yang tidak dapat berfungsi secara optimal sehingga akan membuat responden merasa tidak berdaya karena perannya dalam kehidupan sehari-hari pun berkurang, sehingga mempunyai perasaan beban keluarga karna tidak dapat seaktif dan sebebas dulu ketika tidak mengalami perubahan fisik. Terjadinya perubahan fisik dan seperti penglihatan mata (penglihatan kabur/rabun), mudah lelah dan ulkus diabetikum faktor tersebutlah yang menyebabkan tingginya kejadian stres pada penderita Diabetes Mellitus. Hal inilah yang akhirnya mempengaruhi citra tubuh sehingga mempengaruhi stres pada responden yang mengalami penyakit Diabetes Mellitus. Kesulitan dalam penelitian ini yaitu peneliti harus mendatangi satu persatu rumah responde

\section{Simpulan}

Ada hubungan Citra tubuh dengan stres pada penderita diabetes mellitus di wilayah kerja Puskesmas Pringsewu.

\section{Saran}

Hasil penelitian ini diharapkan dapat menjadi masukan bagi masyarakat khususnya penderita Diabetes mellitus untuk selalu berfikir positif dalam upaya mencegah terjadinya stres. Dan bagi tenaga kesehatan dapat dijadikan acuan untuk memberikan pendidikan kesehatan bagi masyarakat baik yang mengalami diabetes

mellitus.

\section{Daftar Pustaka}

1. Aditama (2012). Kemitraan Pemerintah dan Swasta dalam Pengendalian Diabetes Mellitus di Indonesia.

2. Smeltzer, S. C., et al. (2010). Brunner \& Suddarth's textbook of medical surgical nursing. Philadelphia, Lippincott Williams \& Wilkins.

3. Yosep, I. (2009). Keperawatan Jiwa. Bandung, Refika Aditama.

4. Kozier, e. a. (2010). Fundamental Keperawatan Konsep, Proses, \& Praktik. Jakarta, EGC

5. Keliat, B. A., Helena. N., \& Farida. P (2011). Manajemen Keperawatan Psikososial \& Kader Kesehatan Jiwa. Jakarta : EGC.

6. Nugroho, T. (2011). Asuhan Keperawatan Maternitas, Anak, Bedah Dan Penyakit Dalam. Yogyakarta : Nuha Medika

7. Riset Kesehatan Dasar 2013

8. Notoatmodjo, S. (2012). Metodologi Penelitian Kesehatan. Jakarta, Rineka Cipta

9. Kusumawati, F \& Hartono, Y. (2010). Buku Ajar Keperawatan Jiwa, Jakarta : Salemba Medika.

10. Nasir, A. and M. Abdul (2011). Dasar dasar keperawatan jiwa. Jakarta, Salemba Medika 
11. Umar. R, R. J. V., Lolong. J (2016).

"Hubungan Stres Dengan Citra Tubuh pada Penderita Diabetes Mellitus Tipe II di Rumah Sakit Pancaran Kasih Gmim Manado 2016

12. Lewis, S., Heitkemper, M., Dirksen, S. (2004). Medical Surgical Nursing: Assesment and Management of Clinical Problem. Missouri: Mosby. 